\title{
The removal of chloramphenicol from water through adsorption on activated carbon
}

\author{
Joanna Lach ${ }^{1, *}$, Agnieszka Ociepa-Kubicka² \\ ${ }^{1}$ Czestochowa University of Technology, Faculty of Infrastructure and Environment, ul. Brzeźnicka 60a, 42-200 Częstochowa, \\ Poland \\ ${ }^{2}$ Czestochowa University of Technology, Faculty of Management, Armii Krajowej 19 B, 42-200 Częstochowa, Poland
}

\begin{abstract}
The presented research investigated the removal of chloramphenicol from water solutions on selected activated carbon available in three grades with different porous structure and surface chemical composition. Two models of adsorption kinetics were examined, i.e. the pseudo-first order and the pseudosecond order models. For all examined cases, the results of tests with higher value of coefficient $\mathrm{R}^{2}$ were described by the equation for pseudo-second order kinetics. The adsorption kinetics was also investigated on the activated carbons modified with ozone. The measurements were taken from the solutions with $\mathrm{pH}$ values of 2 and 7. Chloramphenicol was the most efficiently adsorbed on the activated carbon F-300 from the solutions with $\mathrm{pH}=7$, and on the activated carbon ROW 08 Supra from the solutions with $\mathrm{pH}=2$. The adsorption of this antibiotic was in the majority of cases higher from the solutions with $\mathrm{pH}=2$ than $\mathrm{pH}=7$. The modification of the activated carbons with ozone enhanced their adsorption capacities for chloramphenicol. The adsorption is influenced by the modification method of activated carbon (i.e. the duration of ozonation of the activated carbon solution and the solution temperature). The results were described with the Freundlich and Langmuir adsorption isotherm equations. Both models well described the obtained results (high $\mathrm{R}^{2}$ values).
\end{abstract}

\section{Introduction}

One of the new types of contaminants that can be found in water and wastewater are pharmaceuticals. The presence of drugs in treated wastewater was reported as early as in 1976 (clofibric acid - USA) [1]. Since that time, a wide range of almost all pharmaceutical types have been found in untreated and treated wastewater, surface water and even drinking water [2].

The presence of pharmaceuticals in wastewater is due to their common use in the prophylaxis and treatment of people and animals as well as in agriculture (including fish farming) [3] and therefore, the pharmaceuticals are found in municipal wastewater. The highest concentrations of pharmaceuticals are observed in wastewater from hospitals and pharmaceutical manufacturing plants [4].

One of the major groups of pharmaceuticals are antibiotics. The invention of penicillin by Alexander Fleming in 1928 marked a breakthrough in medicine. It is considered one of the greatest inventions of the 20th century. Unfortunately, very soon, a drug-resistance phenomenon was started to be observed (in the mid-30s of the 20th century for sulphonamides and in the second half of the $40 \mathrm{~s}$ for penicillin and streptomycin). Currently, drug resistance has become a global problem [5]. In Europe, it is estimated that 25000 of patients die because of infections caused by drug resistant bacterial strains. In the USA, as many as $70 \%$ bacteria involved in hospital infections are resistant to at least one antibiotic $[6,7]$. The currently observed presence of antibiotics in surface water and, consequently, in drinking water is dangerous for the functioning of the environment and for human health [8].

Prolonged exposure, even to low antibiotic concentrations can: reduce the human immunity, have carcinogenic teratogenic or mutagenic properties or, having an effect similar to that of hormones, disturb the proper functioning of the human organism [9]. An unavoidable and, probably, the key result is the emergence of super-bacteria resistant to all antibiotics [10].

Removal of various contaminants through adsorption on activated carbon can be used for a wide variety of applications. It allows the removal of both inorganic and organic compounds from water and wastewater [11]. Different types of antibiotics can be effectively removed by this method [12-14].

The paper reports the results obtained from the study on the adsorption rate of chloramphenicol on three different grades of activated carbon that are widely used in water treatment. The study aimed to compare the selected activated carbons and to determine the effect of $\mathrm{pH}$ and temperature on the adsorption efficiency. The paper also presents the efficiency of chloramphenicol adsorption on the activated carbon modified with ozone.

\footnotetext{
*Corresponding author: jlach@is.pcz.czest.pl
} 


\section{Materials and methods}

The water adsorption tests were conducted under static conditions by adding $1 \mathrm{~g}$ of activated carbon to $250 \mathrm{~cm}^{3}$ of the solution, while stirring it on a mechanical shaker at the rotating speed of $160 \mathrm{rpm}$. The adsorption kinetics tests were conducted for the initial concentration of 0.5 $\mathrm{mmol} / \mathrm{dm}^{3}$, whereas the adsorption isotherm tests for the concentrations of $0.05 ; 0.1 ; 0.2 ; 0.5$ and $1.0 \mathrm{mmol} / \mathrm{dm}^{3}$ from the solutions with $\mathrm{pH}=2 ; 4 ; 6 ; 8$ and 10 , respectively. The $\mathrm{pH}$ value was regulated using the solution of $\mathrm{HCl}$ or $\mathrm{NaOH}$. Because of high efficiencies of adsorption on the modified carbons, the adsorption efficiency tests were carried out for the concentration of $1.5 \mathrm{mmol} / \mathrm{dm}^{3}$.

The influence of temperature on the adsorption process was determined for the solutions at the temperature of 20,30 and $40^{\circ} \mathrm{C}$, respectively, using a shaking water bath.

The activated carbons were modified with ozone in a water solution at different temperatures (20, 40 and $60^{\circ} \mathrm{C}$ ). The $150 \mathrm{~g}$ sample of activated carbon was transferred into each Erlenmeyer flask and $300 \mathrm{~cm}^{3}$ of distilled water was added. Then the flask was placed in the water bath. This mixture was purged with ozone at the concentration of $3 \mathrm{mg} / \mathrm{dm}^{3}$ and the flow rate of 40 $\mathrm{mg} / \mathrm{dm}^{3}$. This modification process was continued for 60 and 120 minutes, respectively. The tests were conducted for three activated carbon grades with the characteristics given in Table 1 [13].

Table 1. Physical and chemical properties of activated carbons (PN-83/C-97555) [15].

\begin{tabular}{|c|c|c|c|}
\hline \multirow{2}{*}{ Parameter } & \multicolumn{3}{|c|}{ Activated carbons } \\
\cline { 2 - 4 } & ROW 08 & F-300 & WG-12 \\
\hline Bulk density,, g/dm ${ }^{3}$ & 417 & 542 & 450 \\
\hline Surface area, m²/g & 890 & 859 & 1098 \\
\hline Water absorption, cm cm $^{3}$ & 0,97 & 0,72 & 0,61 \\
\hline Mechanical strength, \% & 98 & 97 & 98 \\
\hline \multicolumn{1}{|c|}{ pH of water extract } & 8,6 & 6,8 & 6,8 \\
\hline $\begin{array}{l}\text { Methylene blue number, } \\
\text { LM } \\
\begin{array}{l}\text { Iodine adsorption, LI, } \\
\text { mg/g }\end{array}\end{array}$ & 760 & 1055 & 1117 \\
\hline
\end{tabular}

Chloramphenicol (Chloromycetin) used in this study was manufactured by Sigma-Aldrich (Fig. 1).

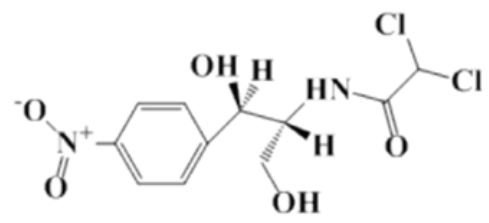

Fig. 1. The structural formula of chloramphenicol.
The molecular weight is $323.14 \mathrm{~g} / \mathrm{mol}$ and the chemical formula is $\mathrm{C}_{11} \mathrm{H}_{12} \mathrm{Cl}_{2} \mathrm{~N}_{2} \mathrm{O}_{5}, \mathrm{pKa}=5.5$. The concentration of chloramphenicol was determined spectrophotometrically at the wavelength of $\lambda=278$.

The adsorption isotherms were described with the Langmuir and Freundlich equations (Table 2).

Table 2. Isotherms and their linear forms.

\begin{tabular}{|l|c|c|}
\hline \multicolumn{2}{|c|}{ Isotherm } & Linear form \\
\hline $\begin{array}{l}\text { Lang- } \\
\text { muir }\end{array}$ & $q=\frac{q_{m} K_{L} C_{e}}{1+K_{L} C_{e}}$ & $\frac{1}{q}=\left(\frac{1}{K_{L} \cdot q_{m}}\right) \frac{1}{C_{e}}+\frac{1}{q_{m}}$ \\
\hline $\begin{array}{l}\text { Freun- } \\
\text { dlich }\end{array}$ & $q=K_{F} C_{e}^{\frac{1}{n}}$ & $\ln Q=\frac{1}{n} \ln C_{e}+\ln K_{F}$ \\
\hline
\end{tabular}

where:

$\mathrm{q}$ is the amount of metal ions adsorbed per unit mass of adsorbent $(\mathrm{mg} / \mathrm{g}), \mathrm{C}_{\mathrm{e}}$ - equilibrium concentration of the solute in the bulk solution $\left(\mathrm{mg} / \mathrm{dm}^{3}\right), \mathrm{q}_{\mathrm{m}}$ - the solid phase concentration corresponding to the complete monolayer coverage of adsorption sites, $\mathrm{K}_{\mathrm{L}}$ - the constant related to the free energy of adsorption, $\mathrm{K}_{\mathrm{F}}$ - Freundlich isotherm constants, $\mathrm{n}$ - adsorption intensity.

Various models have been suggested to describe the kinetics of adsorption of the solute molecules on the sorbent. The $\mathrm{Pb}$ adsorption kinetics data were correlated with the adsorption kinetic models [16]:

- $\quad$ the pseudo-first-order kinetic model

$$
\log \left(q_{e}-q_{t}\right)=\log q_{e}-\frac{k_{1}}{2.303} t
$$

- $\quad$ the pseudo-second-order kinetic model

$$
\frac{t}{q_{t}}=\frac{1}{k_{2} q_{e}^{2}}+\frac{1}{q_{e}} t
$$

where:

$\mathrm{k}_{1}$ is the rate constant for the pseudo-first-order kinetic model, $\mathrm{k}_{2}$ is the rate constant for the pseudo-second-order kinetic model,

$\mathrm{q}_{\mathrm{e}}$ is the amount of solute adsorbed et equilibrium and $\mathrm{q}_{t}$ is the amount of solvent adsorbed at time $t$.

\section{Results and discussion}

At the first testing stage, the kinetics of chloramphenicol adsorption from the solution with the concentration of $0.5 \mathrm{mmol} / \mathrm{dm}^{3}$ on three activated carbon grades (WG-12, F-300 and ROW 08 Supra) was examined (Fig. 2). The equilibrium was first reached (after $7 \mathrm{hrs}$ ) for the activated carbon with the grade ROW 08 Supra. For the remaining two activated carbons the time to reach the equilibrium was much longer and amounting to $9.5 \mathrm{hrs}$. The equilibrium constants of 
adsorption kinetics were determined and presented in Table 3. The chloramphenicol adsorption kinetics followed the pseudo-second order model, as indicated by higher values of the correlation coefficients (Table 3 ).

The effect of $\mathrm{pH}$ on the efficiency of chloramphenicol adsorption on the activated carbon WG-12 was examined (Fig. 3). The highest efficiencies were achieved for the process proceeding from the solution with $\mathrm{pH}=2$, while slightly poorer efficiencies were reported for the solution with $\mathrm{pH}=4$. The rates of chloramphenicol adsorption from the solutions with $\mathrm{pH}=$ 6.8 and 10 were similar, but lower than for $\mathrm{pH}=2$ and 4 . This is most likely due to the fact that chloramphenicol undergoes dissociation at higher $\mathrm{pH}$ values and nondissociated molecules (predominating at $\mathrm{pH}=2$ and $\mathrm{pH}$ =4) are more efficiently adsorbed compared to dissociated ones. The obtained isotherms were described with the Langmuir and Freundlich model (Table 4). Both model types with high values of the correlation coefficient $\mathrm{R}^{2}$ described the obtained test results.

Also, the effect of the solution temperature (in the range from 20 to $40^{\circ} \mathrm{C}$ ) on the efficiency of chloramphenicol adsorption was determined in this study (Fig. 4, Table 5). It was observed that the higher the adsorption temperature was, the higher the adsorption efficiency was reported. The differences were not large.

Taking into consideration unmodified activated carbons it was found that chloramphenicol was best adsorbed on the activated carbon F-300 from the solutions with $\mathrm{pH}=7$, and on the activated carbon $\mathrm{ROW}$ 08 Supra from the solutions with $\mathrm{pH}=2$. The efficiency of adsorption on the carbons modified with ozone was examined. In the case of all investigated activated carbons with different grades, the efficiencies of chloramphenicol adsorption were higher on modified activated carbons (Table 6). For the activated carbons WG-12 and ROW 08 Supra it was noted that the higher the temperature and the longer the modification time, the more efficient the adsorption of chloramphenicol was. In the case of the activated carbon F-300, the optimal modification temperature was $20^{\circ} \mathrm{C}$. The obtained results can be associated with the increase in the specific surface area of the activated carbons due to the modification with ozone [17]. The modification of activated carbon enables also the change of the chemical structure of the activated carbon surface. It was found that ozone led to the increase in the number of acid groups (capable of exchanging anions) as well as basic groups (capable of exchanging anions) [18]. The highest adsorption efficiency $(94.7 \%)$ was observed when the process proceeded from the solution with $\mathrm{pH}=2$ on the activated carbon F-300 modified with ozone at $20^{\circ} \mathrm{C}$ for 120 minutes. The most significant differences in the adsorption efficiency were observed for the process proceeding from the solution with $\mathrm{pH}=7$. The efficiency of adsorption on the unmodified activated carbon WG-
12 was $72 \%$, whereas on the activated carbon modified at $60^{\circ} \mathrm{C}$ for 120 minutes, it amounted to $89.3 \%$.

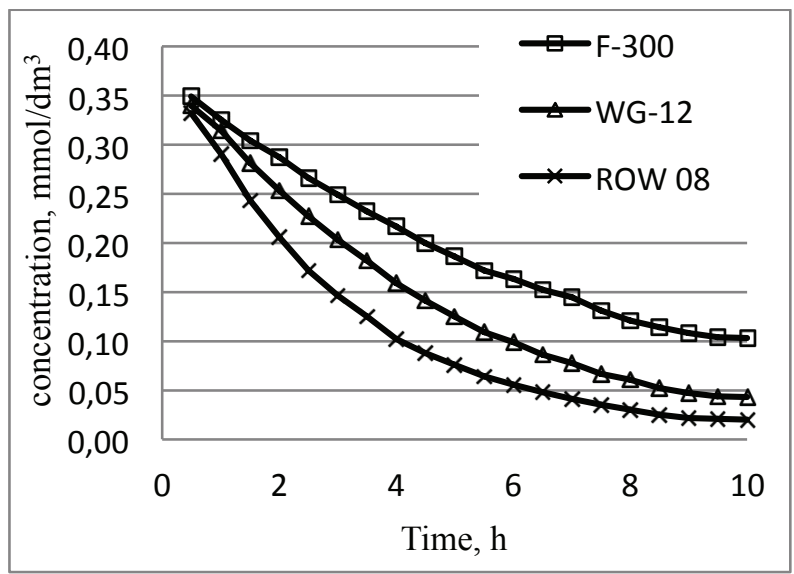

Fig. 2. Kinetics of chloramphenicol adsorption.

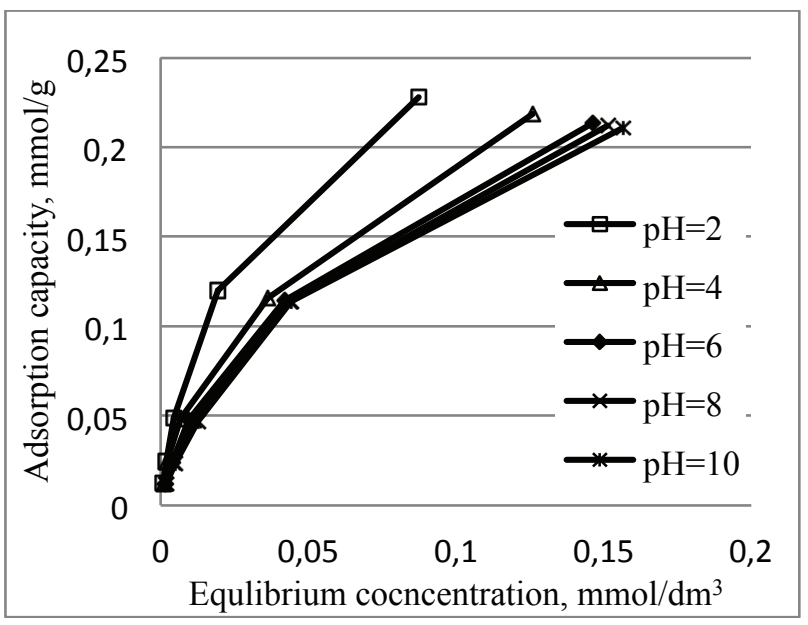

Fig. 3. Effect of the solution $\mathrm{pH}$ on the adsorption of chloramphenicol.

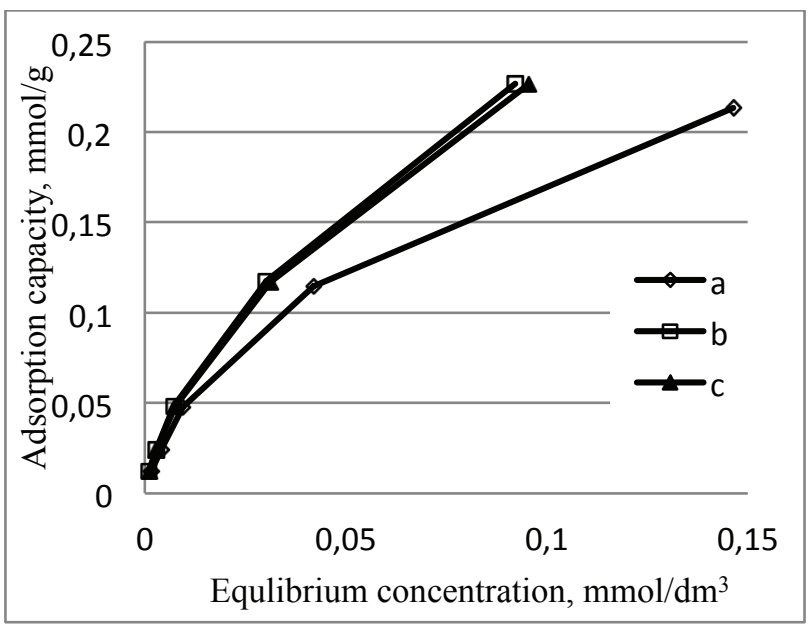

Fig. 4. Effect of temperature on the adsorption of chloramphenicol: $\mathrm{a}-20^{\circ} \mathrm{C}, \mathrm{b}-30^{\circ} \mathrm{C}, \mathrm{c}-40^{\circ} \mathrm{C}$. 
Table 3. Pseudo first- and pseudo second-order rate constants for the adsorption of chloramphenicol on the activated carbons.

\begin{tabular}{|c|c|c|c|c|c|}
\hline \multirow{2}{*}{$\begin{array}{c}\text { Activated } \\
\text { carbon }\end{array}$} & $\begin{array}{c}\mathrm{q}_{\mathrm{e}}(\mathrm{exp}) \\
\mathrm{mg} / \mathrm{g}\end{array}$ & \multicolumn{2}{|c|}{ First-order kinetic model } & \multicolumn{2}{c|}{ Second-order kinetic model } \\
\cline { 2 - 6 } & & $\begin{array}{c}\mathrm{k}_{1} \\
1 / \mathrm{h}\end{array}$ & $\mathrm{R}^{2}$ & $\begin{array}{c}\mathrm{k}_{2} \\
\mathrm{~g} /(\mathrm{mmol} \mathrm{h})\end{array}$ & $\mathrm{R}^{2}$ \\
\hline ROW 08 & 0.120 & 0.051 & 0.8991 & 9.799 & 0.9978 \\
\hline F-300 & 0.099 & 0.046 & 0.8110 & 12.245 & 0.9889 \\
\hline WG-12 & 0.114 & 0.052 & 0.9648 & 10.773 & 0.9832 \\
\hline
\end{tabular}

Table 4. The values of Freundlich and Langmuir constants for the adsorption of chloramphenicol.

\begin{tabular}{|l|l|c|c|c|c|c|}
\hline \multirow{2}{*}{ Isotherm } & \multicolumn{1}{|c|}{ Constants } & \multicolumn{5}{c|}{$\mathrm{pH}$ of the solution } \\
\cline { 3 - 7 } & & 2 & 4 & 6 & 8 & 10 \\
\hline \multirow{3}{*}{ Freundlich } & $\mathrm{K}_{\mathrm{F}}, \mathrm{mmol} / \mathrm{kg}$ & 1.22 & 0.82 & 0.81 & 0.81 & 0.81 \\
\cline { 2 - 7 } & $1 / \mathrm{n},-$ & 0.63 & 0.60 & 0.64 & 0.66 & 0.67 \\
\cline { 2 - 7 } & $\mathrm{R}^{2}$ & 0.9815 & 0.9853 & 0.9906 & 0.9930 & 0.9935 \\
\hline \multirow{3}{*}{ Langmuir } & $\mathrm{q}_{\mathrm{m}}, \mathrm{mmol} / \mathrm{g}$ & 0.203 & 0.194 & 0.165 & 0.167 & 0.150 \\
\cline { 2 - 7 } & $\mathrm{K}_{\mathrm{l}}, \mathrm{dm}^{3} / \mathrm{mmol}$ & 74.08 & 57.53 & 46.33 & 40.43 & 42.48 \\
\cline { 2 - 7 } & $\mathrm{R}^{2}$ & 0.9920 & 0.9951 & 0.9957 & 0.9965 & 0.9915 \\
\hline
\end{tabular}

Table 5. The values of Freundlich and Langmuir constants for the adsorption of chloramphenicol.

\begin{tabular}{|l|l|c|c|c|}
\hline \multirow{2}{*}{ Isotherm } & \multicolumn{1}{|c|}{ Constant } & \multicolumn{3}{|c|}{ Process temperature, ${ }^{\circ} \mathrm{C}$} \\
\cline { 3 - 5 } & & 20 & 30 & 40 \\
\hline Freundlich & $\mathrm{K}_{\mathrm{F}}, \mathrm{mmol} / \mathrm{kg}$ & 1.07 & 1.14 & 1.10 \\
\cline { 2 - 5 } & $1 / \mathrm{n},-$ & 1.32 & 0.66 & 0.65 \\
\cline { 2 - 5 } & $\mathrm{R}^{2}$ & 0.9464 & 0.9979 & 0.9981 \\
\hline Langmuir & $\mathrm{q}_{\mathrm{m}}, \mathrm{mmol} / \mathrm{g}$ & 0.165 & 0.138 & 0.145 \\
\cline { 2 - 5 } & $\mathrm{K}_{\mathrm{l}}, \mathrm{dm}^{3} / \mathrm{mmol}$ & 46.33 & 87.66 & 80.71 \\
\cline { 2 - 5 } & $\mathrm{R}^{2}$ & 0.9959 & 0.9865 & 0.9911 \\
\hline
\end{tabular}

Table 6. The efficiency of chloramphenicol adsorption from the solutions with the concentration of $1.5 \mathrm{mmol} / \mathrm{dm}^{3}, \%$.

\begin{tabular}{|c|c|c|}
\hline \multirow[t]{2}{*}{ Activated carbons } & \multicolumn{2}{|c|}{$\mathrm{pH}$ solution } \\
\hline & 2 & 7 \\
\hline \multicolumn{3}{|c|}{ Activated carbon type WG-12 } \\
\hline WG-12 & 83.3 & 72.0 \\
\hline WG-12- $\mathrm{O}_{3}-120 \min 20^{\circ} \mathrm{C}$ & 92.0 & 88.7 \\
\hline WG- $12-\mathrm{O}_{3}-60 \min 40^{\circ} \mathrm{C}$ & 92.0 & 87.3 \\
\hline WG-12-O $\mathrm{O}_{3}-120 \min 40^{\circ} \mathrm{C}$ & 90.0 & 85.3 \\
\hline WG-12-O $-60 \min 60^{\circ} \mathrm{C}$ & 89.3 & 84.7 \\
\hline WG-12-O $-120 \min 60^{\circ} \mathrm{C}$ & 93.3 & 89.3 \\
\hline \multicolumn{3}{|c|}{ Activated carbon type ROW 08 Supra } \\
\hline ROW 08 & 90.0 & 88.7 \\
\hline ROW $08-\mathrm{O}_{3}-60 \min 20^{\circ} \mathrm{C}$ & 93.3 & 94.0 \\
\hline ROW $08-\mathrm{O}_{3}-120 \min 20^{\circ} \mathrm{C}$ & 93.3 & 92.0 \\
\hline
\end{tabular}


Table 6 (cont.)

\begin{tabular}{|l|c|c|}
\hline ROW 08- ${ }_{3}-60 \min 40^{\circ} \mathrm{C}$ & 94.0 & 92.7 \\
\hline ROW 08- $\mathrm{O}_{3}-120 \min 40^{\circ} \mathrm{C}$ & 94.7 & 92.0 \\
\hline \multicolumn{2}{|c|}{ Activated carbon type F-300 } \\
\hline F-300 & 88.0 & 90.7 \\
\hline F-300- $\mathrm{O}_{3}-60 \min 20^{\circ} \mathrm{C}$ & 92.0 & 90.7 \\
\hline $\mathrm{F}-300-\mathrm{O}_{3}-120 \min 20^{\circ} \mathrm{C}$ & 94.7 & 90.7 \\
\hline $\mathrm{F}-300-\mathrm{O}_{3}-60 \min 40^{\circ} \mathrm{C}$ & 90.7 & 88.0 \\
\hline $\mathrm{F}-300-\mathrm{O}_{3}-120 \min 40^{\circ} \mathrm{C}$ & 91.3 & 86.7 \\
\hline
\end{tabular}

\section{Conclusions}

The adsorption of chloramphenicol on the investigated activated carbons WG-12, F-300 and ROW 0 followed the pseudo-second order kinetics equation. Considering the unmodified activated carbons it was found that chloramphenicol was the most efficiently adsorbed on the activated carbon F-300 from the solutions with $\mathrm{pH}=7$, and on the activated carbon ROW 08 Supra from the solutions with $\mathrm{pH}=2$. When examining the effect of the solution $\mathrm{pH}$ on the adsorption rate it was found that the lower the solution $\mathrm{pH}$ was, the larger the capacity of the activated carbon was reported. This is the result of more favorable adsorption of nondissociated molecules which predominated in acid solutions. Higher adsorption efficiency was observed when the process proceeded from the solution at the temperature of $40^{\circ} \mathrm{C}$, compared to $30^{\circ} \mathrm{C}$ or $20^{\circ} \mathrm{C}$, but the differences were not large. The modification of the activated carbons with ozone resulted in the increase in their adsorption capacities with respect to chloramphenicol. The optimal modification temperature and duration depended on the activated carbon type.

Acknowledgements: This research was financed from the statutory grant No. BS/PB - 401/301/12.

\section{References}

1. K. Sosnowska, K. Styszko-Grochowiak, J. Gołaś, Krakowska Konferencja Młodych Uczonych, 395, (2009)

2. A. Szymonik, J. Lach, K. Malińska, Chem. Eng. S. 24/1, 65 (2017)

3. F. Yu, Y. Li, S. Hans, J. Ma, Chemosphere 153, 365 (2016)

4. A. Koszowska , M. Ebisz, T. Krzyśko-Łupicka, Environmental Medicine 18/1, 62 (2015)

5. Z. Markiewicz, Z. A. Kwiatkowski, Bakterie, antybiotyki, lekooporność. (Wyd. Naukowe PWN, Warszawa, 2012)

6. D. Żabicka, E. Literacka, K. Bojarska, Aktualności NPOA 3, 1 (2012)
7. L. Bruton, J.S. Lazo, K.L. Parker., Farmakologia Goodmana \& Gilmana (Wyd. Czelej, Lublin, 2007)

8. L. Wollenberger, B. Halling-Sørensen, K. Kusk, Chemosphere 40, 723 (2000)

9. O.A. Jones. J.N. Lester, N. Voulvoulis Trends Biotechnol. 23, 163 (2005)

10. J.L. Martínez, Environ. Pollut. 157, 2893 (2009)

11. J. Lach, E. Okoniewska, L. Stępniak, A. OciepaKubicka, Desalin. and Water Treat. 523979 (2014)

12. E. Bocos, E. Alfaya, O. Iglesias, M. Pazos, M. Á. Sanromán, Sep. Purif. Technol. 151, 243 (2015)

13. X. Zhang, W. Guo, H.H. Ngo, H. Wen, N. Li, W. Wu, J. Environ. Manage. 172, 193 (2016)

14. L. Qin, Z. Zhou, J. Dai, P. Ma, H. Zhao, J. He, A. Xie, C. Li, Y. Yan, J. Taiwan Inst. Chem. E. 62, 228 (2016)

15. J.Lach, E. Okoniewska, L. Stępniak, E. Ociepa, Ann. Set Environ. Prot. 15/3, 2142 (2013)

16. L. Largitte, R. Pasquier, Chem. Eng. Res. Des. 109, 495 (2016)

17. J. Rivera-Utrilla, M. Sánchez-Polo, Chemosphere 65, 1131 (2006)

18. M. Sa'nchez-Polo, U.von Gunten, J. RiveraUtrilla, Water Res. 39, 3189 (2005) 